\title{
Åndsmenneske med kritisk blikk på praksis
}

\author{
Linn Getz synes det er på høy tid å rette litt velment skyts mot det hun kaller forebyggende \\ «godhetsmedisin». - Neglisjerte og krenkede barn er fremtidens multimorbide voksne. \\ Det er der vi må sette inn ressursene, sier Getz.
}

Etter å ha tilbrakt tre timer på en av hovedstadens hyggeligere kafeer sammen med Linn Okkenhaug Getz, føler jeg meg underlig oppløftet og plutselig opplyst. Hun er åpenbart et av disse menneskene som har evnen til å løfte deg ut av hverdagen og tilføre et nytt perspektiv. I dag er mitt daglige legevirke blitt tilført en åndelig dimensjon som ellers er godt skjult bak antall tiltak per dag. Jeg kjenner at jeg faktisk er litt rørt.

- Øyeblikk av samhørighet med pasienten kan oppleves som nærmest hellige for meg, sier Linn Getz.

Den høyreiste damen er like rak i ryggen som hun er klar i talen. - Når vi kommer til selve kjernen, der essensen av problemet er, da fryser jeg på ryggen. Da opplever jeg at vi er i starten på noe konstruktivt. Det er øyeblikk da det skjer noe med både meg og pasienten, forklarer hun på avslepet, men umiskjennelig trøndersk.

Linn Getz har tatt seg tid til å treffe meg under en snarvisitt til Oslo, der hun skal delta på et møte om biomedisin i regi av Legeforeningen. Ellers er programmet stramt - med stadig pendling mellom forskerstillingen ved Norges teknisk-naturvitenskapelige universitet $\mathrm{i}$ Trondheim og jobben som bedriftslege ved sykehuset i Reykjavik. Hun er blitt en etterspurt foredragsholder og skal blant annet være hovedtaler under Primærmedisinsk uke i Oslo i 2010. Dessuten er hun hyret inn til konferanser i Sverige, Spania og Island det kommende året, så det er tydeligvis flere enn meg som har latt seg fascinere av Linns måte å se livet og medisinen på.

\section{Bråkmakeren}

«God kveld, Linn Getz, har De snudd alt på hodet igjen nå?»

Ordene falt på en gallamiddag på Island nylig, og de kom med glimt i øyet fra en av legene i helsetilsynet på den finanskriserammede øya. Det blir nemlig ofte rabalder når fru Getz tar bladet fra munnen. Sist hun gjorde det, var da hun var medarrangør av et symposium på Island der temaet kreftscreening ble problematisert. Etter at hun i sin doktoravhandling tok for seg det teoretiske grunnlaget for individrettet medisinsk forebygging på ulike felter, er hun blitt en pådriver for en kritisk tilnærming til gjeldende praksis. Linn Getz er stadig på jakt etter en bærekraftig og ansvarlig medisin. Grunnlaget for dagens retningslinjer er for tynt på mange områder, mener hun, og det kan føre til uheldig disponering av ressursene.

- Forebyggende medisin basert på fragmentert tenkning har fått stor plass i dagens helsevesen, og jeg mener det er betenkelig at stadig flere faller inn under begrepet «risikopasient» som dermed skal ha forebyggende behandling, mener Getz.

Hun synes det er underlig at den stadig videre definisjonen av «risikopasient» og de stadig lavere intervensjonsgrensene i svært liten grad er blitt problematisert i de medisinske miljøene, til tross for at konsekvensene for samfunnet er enorme. Derfor ser hun seg nødt til å gjøre nettopp det.

- Vi må ha en diskusjon om hvilke prioriteringer som skal gjøres. Ellers vil både kvaliteten, effektiviteten og troverdigheten $\mathrm{i}$ helsevesenet bli redusert, frykter hun.

\section{Mønsterbryteren}

Linn Getz er historien om en flink og strebende jente som la sin ære i å lære faglige retningslinjer til punkt og prikke - inntil hun oppdaget at det var grunn til å stille spørsmål ved medisinens vedtatte sannheter. Spørsmålene ble etter hvert så mange at det ble en doktorgrad av det. Hun oppfattes ofte som modig i medisinskfaglig sammenheng, men hun har erfart at det er viktig ikke å stå alene når man stiller spørsmål ved faglig praksis.

- Jeg møtte mye motstand i de fosterdiagnostiske miljøene da jeg i sin tid stilte spørsmål ved bruk av tidlig ultralyd til fosterdiagnostikken. I ettertid ser jeg at jeg nok var litt naiv som trodde at et kvalifisert, kritisk blikk på eksisterende praksis ville bli applaudert og ønsket velkommen. Sånn er det ikke. Det blir nesten alltid bråk når man stiller spørsmål ved det faglige grunnlaget for de eksisterende retningslinjene innen det jeg kaller «godhetsmedisinen». Med det mener jeg alt det medisinske autoriteter anbefaler friske mennesker å gjøre «til deres eget beste», forklarer hun, før hun fortsetter: - Vi spør oss i liten grad om hvorvidt premissene for det vi driver med, virkelig er holdbare. Det virker også som om en del fagfolks identitet er så nær knyttet opp mot en visjon om å redde liv at de blir helt forblindet. Resultatet blir det jeg $i$ en artikkel har kalt «too much doing and too little thinking» $\mathrm{i}$ forebyggende medisin.

Men hva var det egentlig som skjedde med den flinke piken som fulgte retningslinjene uten å stille ubehagelige spørsmål?

- Jeg begynte i allmennpraksis. Først som turnuslege på Senja, deretter som kommunelege 2 på Karlsøy. Plutselig forsto jeg at det jeg hadde lært på studiet, hadde begrenset relevans for menneskenes levde liv. Tiden på Karlsøy ble for meg en dannelsesreise, og jeg vil gjerne få takke for kvalifisert veiledning av daværende kommunelege 1 Nils Kolstrup, forteller hun med brottsjø og nordnorske fjell i blikket.

Hun henter seg inn igjen, og ler plutselig for seg selv. Det ramlet tydeligvis en absurd tanke inn i hennes allerede hardt arbeidende hjerne.

- Jeg lurer virkelig på hva de gamle kullkameratene mine sier når de leser om hva jeg driver med. De som ikke har truffet meg siden studietiden, får seg nok en overraskelse. Jeg var jo inkarnasjonen av flink pike, en skikkelig nerd var jeg faktisk. Jeg leste og leste og var ikke i nærheten av de eksistensielle kriser som en del dypttenkende studenter forteller om. Det var intet som tydet på at jeg senere skulle bli en faglig «risikosportist» og oppvigler, ler hun.

Behovet for å si fra når noe føles galt, oppsto imidlertid for lenge siden, tror hun. Linn glemmer aldri farens ansiktsuttrykk da katastrofen var et faktum 27. mars 1980. Nordsjøplattformen Alexander Kielland hadde kantret. 123 mennesker døde denne dagen. Jan Reidar Getz var en anerkjent forsker innen skips- og marinkonstruksjon, og 17-årige Linn forsto etter hvert at faren følte skyld for ikke å ha gått offentlig ut med sin bekymring for at noe var galt med sikkerhetsforholdene i Nordsjøen.

- Min far hadde ikke noe formelt ansvar 


\title{
Linn Okkenhaug Getz
}

\author{
Født 9 . august 1962
}

- Ph.d. i samfunnsmedisin ved Norges teknisk-naturvitenskapelige universitet 2006

- Halv stilling som bedriftslege ved universitetssykehuset Landspitali, Reykjavik

- Førsteamanuensis ved Institutt for allmenn- og samfunnsmedisin, Norges teknisk-naturvitenskapelige universitet

- Seniorforsker ved allmennmedisinsk forskningsenhet samme sted

- Mye brukt foredragsholder

Foto Anne Kathrine Sebjørnsen

for det som skjedde, men på avstand hadde han nok kjent en nagende uro. Jeg tror han følte seg tynget over at han ikke hadde gjort noe. I ettertid har jeg innsett at denne hendelsen, og pappas reaksjon på den, lærte meg at man må si fra når noe kjennes feil i ens profesjonelle miljø. Man må alltid ha med seg en sunn skepsis, og når magefølelsen slår inn, bør man tenke over hva det kan handle om, mener hun.

\section{Mennesket i kontekst}

Linn Getz forteller at hun, som bedriftslege i sykehus, stadig opplever at de ansatte analyserer seg selv etter «maskinfeilmodellen» når de blir pasienter. Hun oppfatter dette som symptomatisk for tendensen vi har til å redusere mennesker til organer og systemer fremfor å forstå dem som hele individer i lys av deres personlige historie.

- Jeg hadde nylig en pasient som var helt overmannet av søvnløshet, magesmerter, muskelsmerter og stress. «Systemet har brutt sammen,» sa han, og snakket om seg selv som summen av antall transmittere, hormoner og reseptorer som hadde sluttet å fungere. Jeg synes det kan bli ekstremt fremmedgjørende å snakke om transmitterforstyrrelser i hjernen når folk lever et liv der for eksempel en meningsbærende relasjon står på spill. Er man da som menneske et konglomerat av biologiske fragmenter eller et truet livsprosjekt? Mange såkalt medisinsk uforklarlige symptomer fremstår for meg like mye som uutforskede historier. Svært ofte har en lidelse sin logikk - om vi bare evner å se den.

Den aldri sviktende kommunikasjonen mellom kropp og sjel fikk Linn selv kjenne på da finanskrisen rammet Island i oktober 2008. Kjærligheten til Islands eneste professor i allmennmedisin fikk henne til å flytte fra Norge til Sagaøya i 1996, og i dag lever hun en pendlertilværelse med ett bein $\mathrm{i}$ hvert land både faglig og mentalt. Mens mannen, hennes to egne barn og hennes tre voksne bonusbarn har tilhold i Reykjavik, tilbringer hun selv mye tid på reise. Til tross for at hennes egen familie ikke ble alvorlig rammet av finanskrisen, kjente hun fysisk på maktesløsheten, fortvilelsen og vantroen som inntok Island da landets valuta og selvfølelse forsvant i løpet av få dager.

- Jeg fikk arytmier. Jeg visste at jeg ville ha blitt henvist til sykehus om jeg hadde oppsøkt lege, men jeg tenkte at ingen ville være interessert i det jeg selv opplevde som årsaken. Dette var for meg en grensesprengende, eksistensiell erfaring av kollektiv avmakt. Arytmiene forsvant for godt da den islandske regjeringen omsider gikk av, etter flere dager med heftige demonstrasjoner foran Alltinget, forteller hun.

\section{Oppvekst viktigst}

Den allmennmedisinske ideologien og det helhetlige menneskesynet har preget tankegangen hennes, og det er her hun kjenner seg hjemme faglig. Engasjementet er blant annet kanalisert i en tverrfaglig «tenketank» i regi av allmennmedisinsk forskningsenhet i Trondheim. Der er mandatet å klekke ut kloke tanker om hvilken retning medisinen bør bevege seg i.

- Det produseres så utrolig mye spennende vitenskap, sier hun. - Ikke minst innen moderne stressforskning og psykonevroimmunologi. Og denne nye empirien begynner å avtegne et bilde av den menneskelige biologien som mettet med mening. Dette må få konsekvenser for klinisk praksis. Jeg fokuserer ikke bare på ting jeg mener medisinen bør inneholde mindre av. For tiden er jeg minst like opptatt av å formulere hva vi som leger bør gjøre mer av. Men var jeg helseminister for en dag, skulle jeg rettet oppmerksomheten mot hva en dårlig oppvekst gjør med menneskers helse. Neglisjerte og krenkede barn er fremtidens multimorbide voksne, sier Getz.

I den før nevnte «tenketanken» har man formulert det slik at krenkelser som innebærer at noen defineres som et noe-det vil si at et menneske opplever å bli redusert til et objekt som i hovedsak skal tjene andres interesser eller til en som ingen virkelig bryr seg om - griper dypt inn i fysiologien. Det å bli sett, anerkjent og kjenne at tilværelsen har mening, er nøkkelen til god helse.

- Barns levekår er sannsynligvis det aller viktigste å prioritere om man virkelig vil bidra til god folkehelse. Jeg opplever at jeg blir stadig mer opptatt av fremtidens pasienter, de som ikke er til stede under konsultasjonen, mine voksne pasienters barn. Og jeg har sluttet å vegre meg for å spørre. I samtale med folk som åpenbart lever marginale liv under stort press, spør jeg ikke sjelden om hvordan barna deres har det, hvem som er der for dem? Jeg har ennå ikke opplevd at noen er blitt sint på meg for det, ikke forundret engang. Så da blir vel spørsmålet oppfattet som høyst relevant? Så igjen - hvis jeg fikk bestemme, skulle vi brukt mer tid, penger og ikke minst tankekraft på å utvikle denne delen av medisinen, sier Linn Getz.

\section{Anne Kathrine Sebjørnsen}

annekaths@hotmail.com

BUP Nordstrand 